\title{
KONTEN FOTOGRAFI JURNALISTIK YANG MENJADI VIRAL DI INTERNET
}

\author{
Ellen Agustine Saputra \\ Dosen Desain Komunikasi Visual \\ Universitas Ciputra Surabaya \\ ellen.saputra@ciputra.ac.id
}

\begin{abstract}
With the presence of the Internet, journalistic photography can provide an opportunity to be more noticed by various societies. Social media and other online media accessed by billions of people each day therefore the spread of journalistic photography are wider. In this case the role of photojournalists becomes more crucial, Rothman (2012) explains that the beginning of motivational photojournalist plunge in the world of journalism due to the insistence in their hearts to announce something that is so important therefore they want to make a change. In this research will be discussed some journalistic photography that raised certain themes using content and structure of journalistic photography with significant results, then become viral on the internet. Some journalistic photography can be viral and some are not. The focus of this research is to find out the reasons and similarities in some journalistic photography that became viral on the Internet.

This research uses qualitative content analysis method. Samples were selected based on the virality factor, 4 journalistic photography were taken from various sources and photographed by photographer with different background too. The first photo has been mentioned for 1,890,000 times; the second photo has been mentioned for 32,900,000 times; the third has been accessed for 22,600,000 times and the last has been accessed for 25,270,000,000 times. All four will be discussed based on the theory of journalistic photography, associated with the theory of virality.
\end{abstract}

Keywords: Photojournalistic, viral, content.

Relevance to Visual Communication Design Practice: Konten fotografi jurnalistik khususnya yang menjadi viral di internet dapat menjadi sumber pengetahuan serta referensi baik untuk fotografer, jurnalis, mahasiswa serta masyarakat pada umumnya.

\section{PENDAHULUAN}

Dalam dunia modern, kehadiran kamera $35 \mathrm{~mm}$ Leica di Jerman pada pertengahan tahun 1920 mengubah fungsi sebuah foto pada media massa. Argles (2012) mengemukakan bahwa fotografi jurnalistik adalah ilustrasi dari rangkaian kejadian yang tertuang dalam sebuah foto, dikombinasikan dengan teks. Fotografi jurnalistik mengabarkan berita atau peristiwa penting yang kebanyakan bersifat polemik. Dengan kehadiran internet, fotografi jurnalistik memiliki kesempatan untuk lebih diperhatikan oleh berbagai kalangan. Sosial media dan media online lainnya diakses oleh milyaran orang setiap harinya, sehingga penyebaran fotografi jurnalistik semakin meluas. Disini peran fotojurnalis menjadi semakin krusial, Rothman (2012) menjelaskan bahwa awal mulanya motivasi fotojurnalis terjun dalam dunia jurnalisme dikarenakan desakan dalam hati mereka untuk menceritakan sesuatu yang begitu penting sehingga mereka ingin membuat 
perubahan. Dapat disimpulkan, sebenarnya visi seorang fotojurnalis lebih dari sekedar memberitakan kabar atau informasi terkini, melainkan juga menjadi advokat. Untuk menjadi seorang advokat, seorang fotojurnalis harus memiliki sensitivitas dan emosi untuk mendorong mereka berkarya. (SNAPSHOT, 2016)

\section{ISU LINGKUNGAN}

Isu pencemaran sampah di laut sudah menjadi perbincangan global sejak dipublikasikannya hasil penelitian Jambeck et.al, tahun 2015. "Berdasarkan data Jambeck (2015), Indonesia berada di peringkat kedua dunia penghasil sampah plastik ke laut yang mencapai sebesar 187,2 juta ton setelah China yang mencapai 262,9 juta ton. Lebih dari satu juta kantong plastik digunakan setiap menitnya, dan 50 persen dari kantong plastik tersebut dipakai hanya sekali lalu langsung dibuang." (Wahyuni, 2016). Kondisi ini sangat memprihatinkan, bahkan Pemerintah masih berembuk untuk mencari solusi sampah plastik di laut. (Oktara, 2017) Telah diberitakan bahwa Pemerintah melibatkan kementrian, lembaga serta institusi dalam negeri lainnya mengenai perencanaan aksi nasional penanganan sampah di laut, di samping itu Pemerintah juga berencana untuk bekerja sama dengan negara lain yang memiliki masalah serupa.

Solusi yang sedang dibahas dalam jajaran Pemerintah tidak akan mengurangi jumlah sampah plastik ke laut setiap harinya, sehingga diperlukan kepedulian dan peran aktif masyarakat untuk tidak membuang sampah ke sungai dan mengelola sampah dan mewujudkan Indonesia Bersih Sampah 2020.

\section{ISU PERANG}

Peperangan memberikan dampak yang besar tidak hanya bagi dewasa, melainkan juga anak-anak. Perang merusak ekonomi lokal, agrikultur, industri, pekerjaan serta infrastuktur, dan kenyataan yang terjadi adalah negara-negara yang sedang mengalami peperangan adalah negara miskin. Sehingga dampaknya semakin tidak tertolong. Anakanak tidak mendapat akses atas edukasi, bahkan mereka berakhir di jalanan dengan kemiskinan akut. (UNHCR, 2006)

Menurut statistik, puluhan ribu anak di bawah umur 18 tahun direkrut sebagai tentara perang. Dampaknya, anak-anak ada yang kehilangan salah satu bagian tubuhnya, ataupun kemampuan berpikir. Mereka menjalani sebuah pengalaman traumatik. (Burhani, 2017) Perang merusak rumah sakit dan klinik, jutaan anak-anak yang membutuhkan perawatan akhirnya meninggal karena sakit diare, malaria, kolera, dan lain sebagainya.

Tidak sedikit juga anak-anak yang mengalami PTSD, post-traumatic stress disorder, secara psikologis mereka berkembang dan bertumbuh tanpa mengetahui apa yang sebenarnya terjadi terhadap mereka. Efeknya sungguh sangat mengerikan dibandingkan apabila terjadi kepada orang dewasa. Mereka bertumbuh mengalami diskoneksi dengan orang dewasa, tidak bisa membangun hubungan yang baik dengan siapapun, serta memilih alkohol dan obat-obatan sebagai bentuk pelarian.

Peran fotojurnalis masih dibutuhkan terutama pada keadaan dunia yang bobrok seperti ini. Isu sosial seperti isu lingkungan pun tidak mudah mendapatkan solusi. Terorisme, peperangan, dan kekerasan terus 
terjadi tanpa henti, sehingga dibutuhkan lebih banyak lagi agen ganda seperti fotojurnalis, yang juga berperan sebagai advokat. Melalui tanggung jawab mereka memotret realita, diharapkan kehadiran mereka diapresiasi dan praktik advokasi mereka diturunkan kepada generasi selanjutnya. Dalam penelitian ini akan dibahas beberapa fotografi jurnalistik yang mengangkat tema-tema tertentu menggunakan konten serta struktur fotografi jurnalistik dengan hasil yang signifikan, lalu menjadi viral di internet. Beberapa fotografi jurnalistik ada yang bisa viral dan ada yang tidak. Fokus penelitian ini adalah mencari alasan serta kesamaan pada beberapa fotografi jurnalistik yang menjadi viral di internet.

\section{LANDASAN TEORITIS}

\section{FOTOGRAFI}

Roland Barthes pernah mengatakan sesuatu yang sering dilihat untuk mendapatkan informasi mengenai dunia ini yang juga disebut transparent envelope adalah foto. Tetapi sebenarnya fotografi, seni atau proses yang menghasilkan gambar dan cahaya yang hasilnya lebih dikenal dengan istilah foto, tidak hanya memiliki makna dan fungsi sebatas itu. Menurut Kriebel, fotografi adalah sebuah rekaman dari realita ataupun ekspresi seorang individu yang dibentuk dari kemampuan dan kepekaan dalam menafsirkan suatu obyek. Sedangkan menurut Baudelaire yang dikutip dalam buku Theories of Photography, fotografi adalah sebuah alat penyimpan memori, layaknya sebuah arsip memori.

\section{JURNALISTIK}

Jurnalistik berkaitan dengan berita dan informasi. Jurnalistik adalah proses menggali data, menyusun, membuat keputusan atas fakta mana saja yang harus disertakan dan mana saja yang harus dibuang. Dalam dunia jurnalistik, dibutuhkan kemampuan teknis dan intelektual dari seorang jurnalis untuk mengemas sebuah informasi yang menarik. Pengetahuan praktis dan teoritis tersebut akan sangat membantu seorang jurnalis dalam menganalisa sebuah peristiwa dan kejadian yang sedang terjadi. (Herbert, 1998)

\section{FOTOGRAFI JURNALISTIK}

Gambar, spesifiknya foto memberikan pengaruh yang berbeda daripada teks. Lashmar \& Hill (2014) menuturkan bahwa foto memicu emosi positif ataupun negatif kepada siapapun yang mengkonsumsinya. Evans (1997) dikutip oleh Lashmar \& Hill (2014) menjelaskan pembaca seolah-olah merasakan apa yang tertuang di dalam sebuah foto. Dalam sebuah foto kondisi sedang berperang, pembaca bisa merasakan dirinya berada di tengah-tengah perjuangan para tentara. Subyek serta tema sebuah foto dapat merangsang keseluruhan indera manusia, itulah hebatnya pengaruh sebuah fotografi jurnalistik. Fotografi jurnalistik sering digunakan karena terkadang sebuah rekaman kejadian tidak selalu bisa diungkapkan melalui kata-kata.

Elemen penting dalam fotografi jurnalisitik yang diteliti dalam Through the Objective Lens: The Ethics of Expression and Repression of High Art in Photojournalism adalah sebagai berikut: 


\section{STAGING}

Perdebatan akan kode etik seorang fotojurnalis dalam memotret sebuah realita hingga saat ini belum usai. Fotojurnalis memiliki tanggung jawab tinggi untuk berkomitmen terhadap obyektivitas, sedangkan teknik staging kerap dibutuhkan dalam proses mendapatkan potret kebenaran. Adolph Ochs menyebut teknis tersebut sebagai directional function of photography, yaitu memiliki kontrol penuh dalam mengatur properti, setting, aktor, usaha dalam menentukan apa yang akan terlihat pada gambar tersebut. (Bowers, 2008)

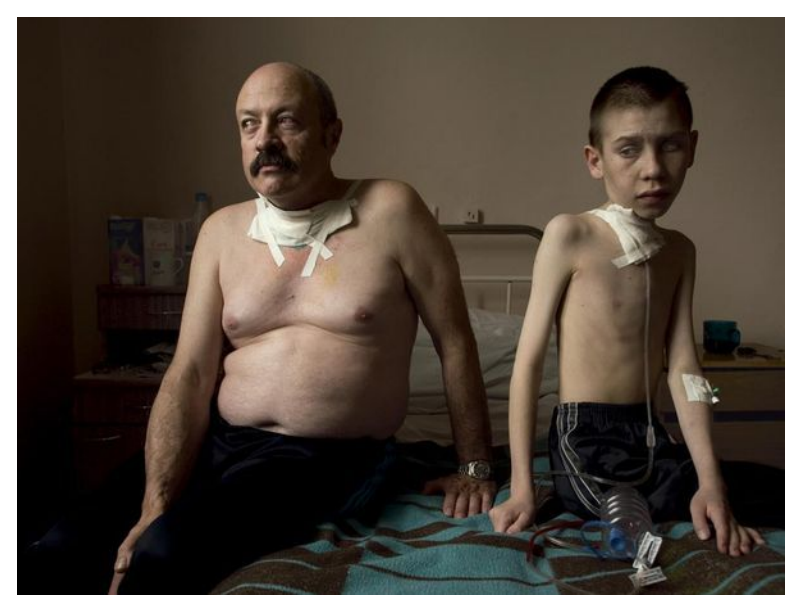

Gambar 1 Oleg Saphiro, 54 tahun (kiri) dan Dima Bognanovich, 13 tahun (kanan) Sumber: What Matters (2008)

Pada contoh foto di atas, foto tersebut diambil oleh Gerd Ludwig di Minsk, Belarus. Foto tersebut efektif dalam penggunaan medium shot, teknik staging ayah melihat ke arah kiri dan anak melihat ke arah kanan menjelaskan arti simbolik mengenai disorientasi mental. Emosi pasrah, bingung, ataupun sedih tercermin dalam muka kedua orang tersebut. Foto ini langsung mengundang simpati dan menimbulkan pertanyaan mendasar bahwa apa yang sebenarnya terjadi kepada keduanya. Pembaca tidak memiliki petunjuk mengenai lokasi ayah dan anak ini dan fotografer sengaja fokus kepada keadaan ayah dan anak pada momen itu, tetapi pembaca mengerti bahwa hal yang sama terjadi kepada keduanya.

Dalam buku yang berjudul What Matters, fotografi milik Gerd Ludwig ini dibahas dalam bab tragedi Chernobyl. Dengan caption foto tersebut berbunyi demikian "Suffering from Thyroid Cancer, Oleg Saphiro 54 tahun, dan Dima Bognanovich, 13 tahun, menerima perawatan intensif di Thyroid Center, Minsk, Belarus. Sebagai seorang likuidator, Shapiro terekspos radiasi yang sangat tinggi sehingga penyakitnya juga menyebabkan anaknya mengalami down syndrome atau kondisi abnormal lainnya.

Fotojurnalis ketika dalam lokasi pemotretan, sangatlah mempertimbangkan apa yang ada dan tidak dalam sebuah foto. Teknik ini disengaja dengan tidak memasukkan suasana lingkungan di sekitarnya, serta teknik staging memungkinkan fotojurnalis memiliki kontrol sehingga subyek foto membayangkan tragedi yang dialaminya sehingga menghasilkan foto yang lebih dramatis. Bowers (2008) memberikan kesimpulan, praktik staging bukan sesuatu yang manipulatif atau korup. Jika teknik tersebut digunakan untuk menghasilkan sesuatu yang memiliki cerita serta kuasa untuk menggugah hati pembaca, maka integritas fotojurnalis selama ini tidak salah.

\section{KOMPOSISI}

Elemen utama dalam sebuah gambar 
yang menarik adalah garis, tekstur dan cahaya. Garis adalah bentuk yang menentukan aspek estetika sebuah gambar, karena melalui garis, fokus mata kita tertuju kemana garis itu mengarah.

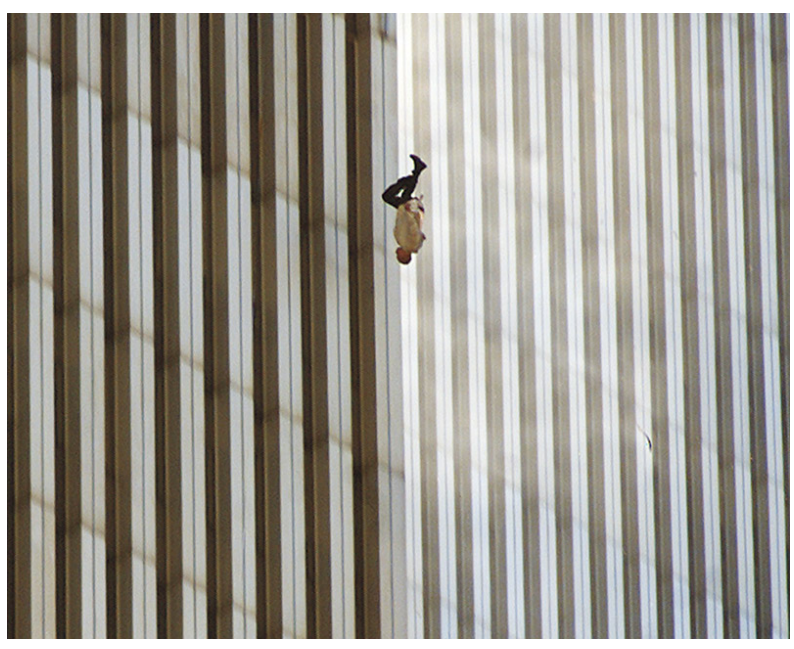

Gambar 2 The Falling Man Sumber: What Matters (2008)

Berikut adalah contoh yang sangat bagus dalam penerapan prinsip garis untuk penekanan komposisi. Foto ini diambil oleh Richard Drew tepat pada tragedi 9/11 World Trade Center. Pola garis horisontal pada gedung sebagai background pendukung dan seorang pria bunuh diri dengan kepala menghadap ke bawah sebagai foreground utama memusatkan mata kita kepada subyek utama foto yaitu the falling man. Junod (2016) mengatakan bahwa tidak ada seorangpun yang tidak terdiam sejenak melihat foto dengan permainan garis ini, karena efek vertikalitas dan simetrikal dalam foto ini memiliki tema yang cukup tragis.

\section{TEKSTUR}

Elemen penting selanjutnya adalah tekstur.
Elemen tekstur memberikan efek realisme dalam sebuah foto, dan elemen tersebut sejalan dengan tujuan utama fotografi jurnalistik yaitu memaparkan kejadian faktual, kejadian yang bersifat nyata.

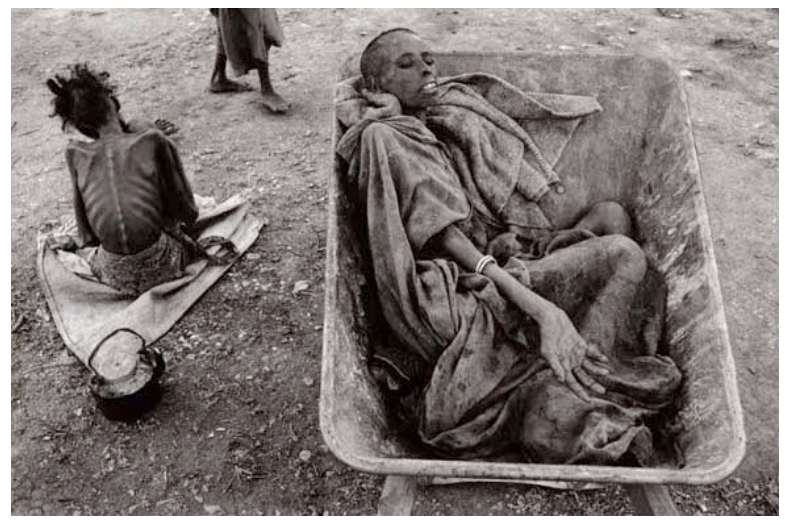

Gambar 3 Kondisi emergency feeding center di Somalia Sumber: What Matters (2008)

Melihat tekstur tulang pada badan wanita yang tampak di sebelah kiri, memunculkan empati bagi pembacanya. Tanpa caption yang terlalu panjang, pembaca dapat langsung menangkap isu kelaparan dan kemiskinan di Somalia. Selain tekstur tulang pada badan wanita, tekstur tanah melebur dengan tekstur alas dan selimut pada wanita di sebelah kanan. Meskipun tidur dengan alas, pembaca dapat mengamsusikan bahwa tidak ada bedanya tidur di atas alas dengan tidur di atas tanah. Yang terakhir adalah elemen cahaya, penerapan elemen ini ada dalam penekanan cahaya terang dan bayangan. Pada foto yang diambil oleh James Nachtwey di Somalia, penggunaan warna hitam dan putih adalah salah satu cara penekanan cahaya terang dan bayangan. Efek karakter yang cenderung gelap dibandingkan dengan warna terang latar memancing kegundahan hati nurani, memberikan efek kosong dan ketidakberdayaan bagi pembaca. 
Garis, tekstur dan cahaya dapat menciptakan komposisi yang mengkomunikasikan realita dan tidak bersifat statik melainkan dinamis sesuai dengan kenyataan dunia ini.

\section{TEMA DAN KONTEN}

Elemen terakhir yang sering digunakan dalam fotografi jurnalistik adalah referensi terhadap tema atau konten tertentu. Penggunaan metafor dan alegori adalah cara dalam menyampaikan tema tertentu. Salah satu contoh yang akan peneliti bahas, foto milik James Nachtwey yang diambil di Nikaragua.

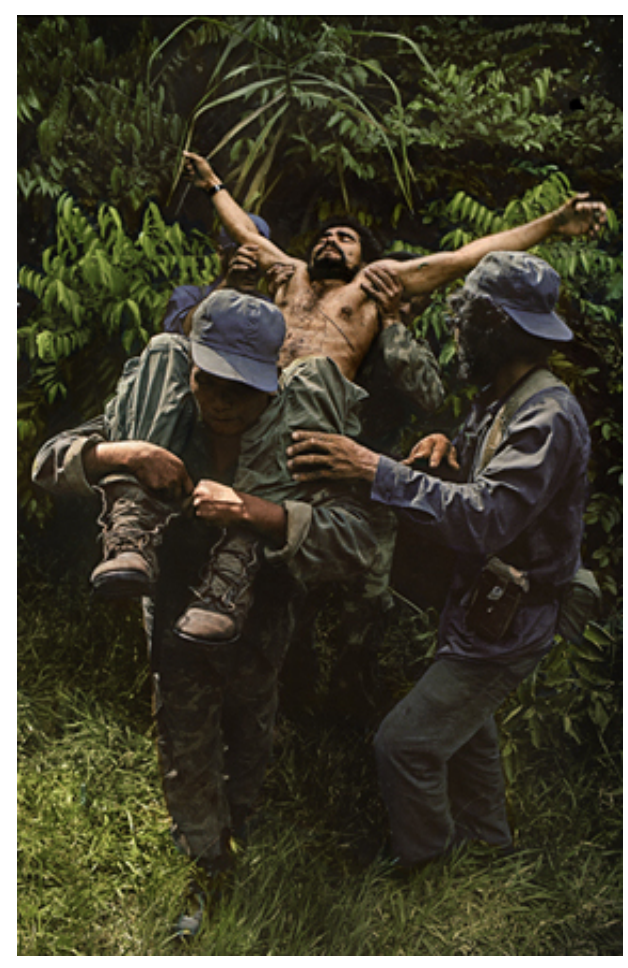

Gambar 4 Tentara yang terluka dalam peperangan di hutan

Sumber: James Nachtwey

https://www.worldpressphoto.org/collection/photo/1985/s pot-news/james-nachtwey. Date accessed: 23 September 2017

Foto tersebut menonjolkan tema religius dan konten yang cukup ikonik, yaitu perang dan penyaliban. Tentara yang terluka itu seperti baru saja disalibkan dan secara tidak langsung memberikan referensi kepada Yesus Kristus.

Ketiga elemen tersebut mewarnai praktik fotografi jurnalistik hingga sekarang, Sebagai fotojurnalis, seseorang harus memiliki pengetahuan teknik visual yang kreatif sehingga membuat mereka dapat memotret kejadian yang unik serta menggugah emosi, bukan hanya informasional.

Arizone State University memperkenalkan sebuah metode yang bernama EDFAT, yang kemudian dijadikan pedoman dalam pemotretan fotografi jurnalistik oleh banyak fotografer. Tahapan yang dilakukan dalam metode EDFAT akan dideskripsikan dalam poin-poin di bawah ini:

- E (Entire). Dikenal sebagai established shot, yaitu suatu keseluruhan pemotretan yang dilakukan begitu melihat suatu peristiwa atau bentuk penugasan lain untuk mengintai bagian-bagian untuk dipilih sebagai obyek.

- D (Detail). Suatu pilihan atas bagian tertentu dari keseluruhan pandangan terdahulu (entire), tahap ini adalah suatu pilihan pengambilan keputusan atas sesuatu yang dinilai tepat sebagai point of interest.

- F (Frame). Suatu tahap dimana fotografer membingkai suatu detail yang telah dipilih. Fase ini mengantar fotografer mengenal arti komposisi, pola, tekstur dan subyek pemotretan dengan akurat. Rasa artistik semakin penting dalam tahap ini.

- A (Angle). Tahap dimana sudut pandang menjadi dominan, memotret dari ketinggian (high angle), bawah (low angle), sejajar (human eye level). 
- $\mathrm{T}$ (Time). Tahap penentuan penyinaran dengan kombinasi yang tepat antara diafragma dan kecepatan. Pengetahuan teknis atas keinginan membekukan gerakan atau memilih ruang tajam adalah salah satu persyaratan yang sangat diperlukan. (Cruz, 2013)

\section{KONSEP VIRALITAS}

Perkembangan teknologi memunculkan berbagai macam media komunikasi baru, Internet adalah salah satu fenomena yang mengubah cara berkomunikasi manusia hingga hari ini. Kehadiran Internet sebagai pusat infrastruktur informasi jaman modern menjadikan konten apapun dapat dengan mudahnya diakses baik melalui komputer atau handphone. Konten online, seperti video, gambar ataupun artikel disebut gone viral jika konten tersebut telah tersebar cepat dan luas di Internet. Menurut penelitian yang berjudul The Structural Virality of Online Diffusion, mekanisme broadcast berbeda dengan mekanisme viralitas. Umumnya diketahui, bahwa dalam praktik broadcast, informasi sengaja disebarkan secara luas dan dapat langsung diterima masyarakat melalui media massa. Konsep viralitas mengusung struktur yang agak sedikit berbeda, mekanisme viralitas dapat digambarkan seperti proses difusi dari bahasan biologi. (Goel, Anderson, Hofman, \& Watts, 2015)

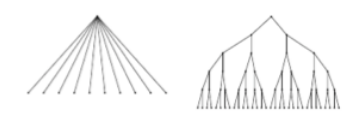

Gambar 5 Perbandingan mekanisme broadcast (kiri) dan struktur viralitas (kanan)

Sumber: Management Science (2015)

Dalam gambar tersebut, terlihat jelas bagaimana struktur viralitas terjadi. Salah satu persamaan konsep broadcast dan viralitas yaitu sama-sama dimulai ketika satu sumber utama menyebarkan sebuah konten. Sebuah konten online, contohnya ketika seseorang menulis post di Facebook, kegiatan tersebut berpotensi menjadi titik permulaan struktur viralitas. Kemudian, mekanisme viralitas benar terjadi ketika satu individu lain menyebarkan lalu direspon oleh minimal tiga individu lainnya dan tiga individu berikutnya meneruskan serta begitu seterusnya. Ada proses penyebaran seperti virus yang menekankan perbedaan konsep viralitas dan broadcast. Viralitas juga melibatkan hubungan kuat antara influencer dan follower. Beberapa penelitian lainnya mengemukakan bahwa influencer atau seseorang yang memiliki pengaruh besar terhadap sekelilingnya, contohnya seperti artis, politikus, aktivis, ataupun kritikus, dimana mereka telah memiliki banyak follower, dapat digolongkan sebagai pemicu viralitas di Internet. Melalui kemampuan alamiah public figure tersebut dalam menyampaikan informasi langsung secara cepat dan diterima apa adanya secara luas oleh pengikutnya, influencer memiliki jaringan sosial yang sangat besar sehingga pengaruh mereka tersebut berpotensi memulai viralitas. (Berger \& Milkman, 2009)

Menariknya melalui data yang dikumpulkan dalam penelitian Goel, Anderson, Hofman, \& Watts (2015), ditemukan bahwa 99\% konten viral tidak terjadi dalam multi generasi. Penyebaran terjadi dalam satu generasi. Korelasi antara popularitas dan viralitas juga cenderung rendah. 


\section{KONTEN FOTO VIRAL DI INTERNET}

Berdasarkan penelitian yang berjudul What Makes Online Content Viral; penulis membahas karakteristik konten yang menyebabkan viralitas. Konten online gone viral memiliki kapasitas pembangkit emosi yang tinggi, contohnya emosi kebahagiaan atau ketakutan. Skala emosi berbeda-beda, sebagai contoh, kapasitas emosi bervariasi mulai dari emosi yang negatif hingga emosi yang positif. Ketakutan adalah kapasitas emosi negatif, sedangkan kebahagiaan adalah ciri kapasitas emosi positif. Tingkatan energi emosi yang tinggi contohnya kemarahan, sebaliknya tingkatan energi emosi yang rendah adalah ketakutan. Level dominansi sebuah emosi juga bervariasi, bergantung pada seberapa besar kontrol yang dimiliki oleh seorang individu. Emosi kekaguman merupakan emosi dengan level dominan yang tinggi, dan emosi ketakutan merupakan emosi dengan level dominan yang rendah. Konten viral tidak selalu memiliki karakteristik konten yang positif, tetapi konten tersebut selalu membangkitkan kapasitas, energi serta dominasi emosi manusia. (Jones, Libert, \& Tynski, 2016)

Dari ketiga karakteristik emosi: kapasitas, energi serta dominansi emosi, faktor kapasitas emosi menjadi faktor terlemah dalam kontribusinya terhadap viralitas. Kedua faktor lainnya memberikan sumbangsih terhadap kesuksesan sebuah viralitas, tetapi data membuktikan bahwa kapasitas emosi negatif lebih berperan pada konsep gone viral.

Kombinasi pembangkit energi serta dominansi emosi adalah penentu konten online bisa menjadi viral atau tidak. Berikut akan dipaparkan hasil emosi melalui diagram kombinasi pembangkit energi dan dominansi emosi:

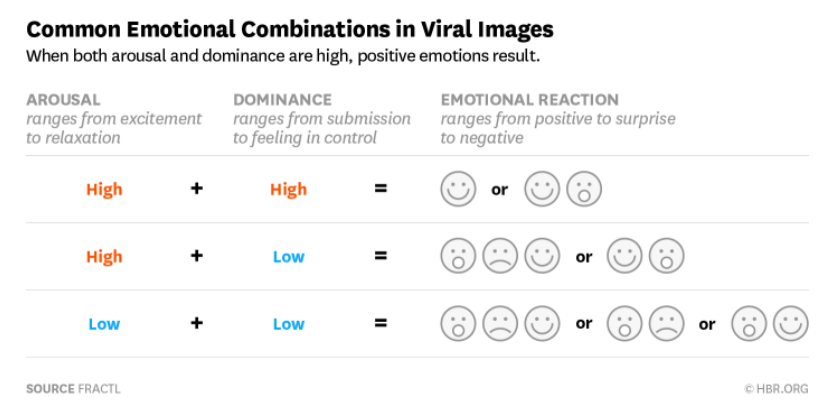

Gambar 6 Perbandingan mekanisme broadcast (kiri) dan struktur viralitas (kanan)

Sumber: Harvard Business Review (2016)

Ketika energi menjadi tinggi dan dominansi juga menjadi tinggi, maka memunculkan element of surprise dari emosi tersebut. Kekaguman, kebahagiaan dan cinta adalah respon emosi yang paling populer.

\section{METODE PENELITIAN}

Penelitian ini menggunakan metode analisa isi. Analisa isi merupakan analisa mendalam dan terinci, menggunakan teknik kualitatif. Jenis analisis yang digunakan adalah analisa isi komunikasi, khususnya fotografi dimana isinya dikategorikan dalam karakteristik tertentu secara obyektif dan sistematis.

"Berelson dalam Kerlinger (1973) menyebutkan, dalam konstruksi kategori, perumusan kategori berhubungan erat dengan variabel penelitian dan tujuan penelitian.” (Kurniawan, 2006)

Menurut White \& Marsh (2006), sample dipilih berdasarkan keunikan serta ketertarikan peneliti. Selama proses penelitian, analisa mendalam mengenai konteks masing-masing fotografi jurnalistik dapat memunculkan berbagai interpretasi. 
Setiap sample tidak harus memiliki persamaan dan bobot yang seimbang, tetapi keduanya harus berhubungan.

Pengumpulan data pada penelitian ini dilakukan melalui proses pengamatan terhadap obyek penelitian. Pengamatan diawali dengan mengamati beberapa fotografi jurnalistik yang viral di internet, kemudian dipilah berdasarkan topiknya.

Sumber data teoritis diambil dari pokok bahasan fotografi, jurnalistik, fotografi jurnalisitik serta viralitas dari jurnal atau buku. Sedangkan sumber data fotografi jurnalistik diambil dari Internet. Teknik analisa data menggunakan 4 fase utama yang dipaparkan oleh Seuring \& Gold (2012), usaha mengutip dari Kassarjian (1977); Krippendorff (1980), dan Mayring (2000):

- Data yang dianalisa telah ditentukan jumlahnya serta unit of analysis telah diputuskan (fase material collection)

- Data dibedah dan dideskripsikan secara rinci berdasarkan latar belakang dan sebagainya (fase descriptive analysis)

- Struktur dan kategori data telah dikelompokkan berdasarkan seleksi tertentu (fase category selection)

- Data dianalisa kembali sesuai dalam ranah kategori yang telah ditentukan (fase material evaluation)

\section{PEMBAHASAN}

Dalam penelitian ini yang dianalisa adalah fotografi jurnalistik yang masuk dalam kategori viral di internet. Foto pertama memiliki kata kunci Seahorse and a Q-Tip, karya milik Justin Hoffman dan foto kedua dengan kata kunci Trash Wave, karya milik Zak Noyle. Keduanya memiliki setting yang sama, karya milik Justin Hoffman dipotret di lautan Sumbawa sedangkan karya milik Zak Noyle dipotret di lautan Jawa. Peneliti memilih keduanya dikarenakan relevansi akan konsep viralitas, di internet, foto Seahorse and a Q-Tip telah disebut sebanyak 1,890,000 dan foto Trash Wave telah disebut sebanyak 32,900,000, berdasarkan data yang Google berikan. Foto ketiga yang berjudul Iraqi Girl at Checkpoint karya Chris Hondros, diakses 22,600,000 kali sedangkan foto keempat yang berjudul Surrendering karya Osman Sagirli, diakes 25,270,000,000 kali.

Pada bab ini akan dibahas 4 fotografi jurnalistik yang telah dikategorikan menjadi 2 bagian, yang pertama mengangkat isu lingkungan, dan yang kedua mengangkat isu perang. Keduanya akan dibahas berdasarkan teori fotografi jurnalistik, dikaitkan dengan teori viralitas.

\section{SEAHORSE AND A Q-TIP DAN TRASH WAVE}

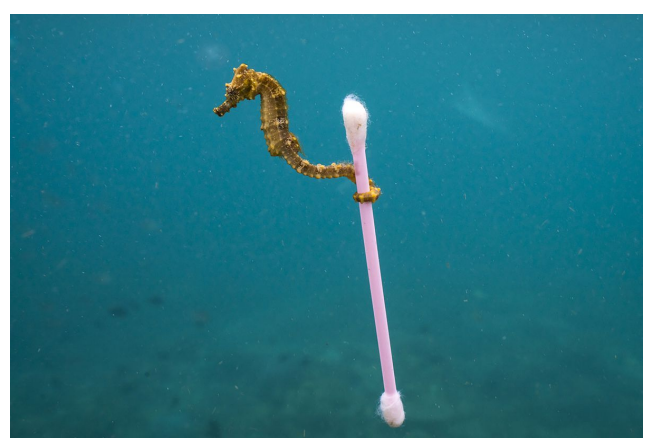

Gambar 7 Seahorse and a Q-Tip Sumber: google.com 


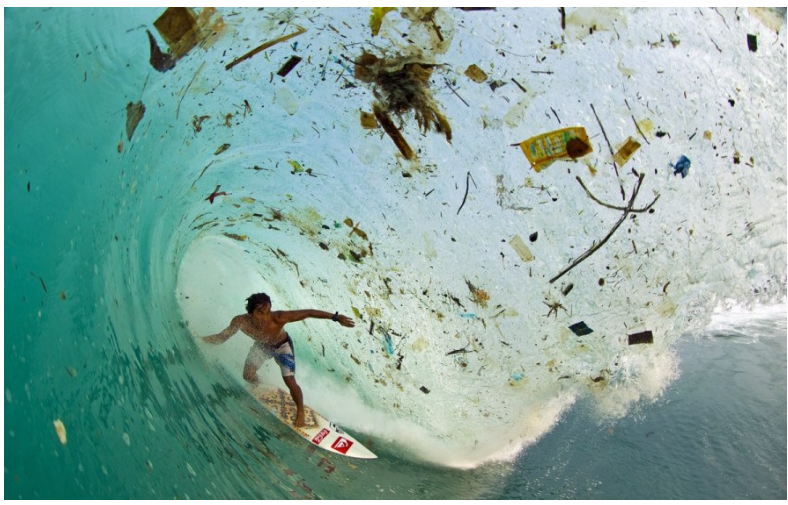

Gambar 8 Trash Wave Sumber: google.com

Kedua foto di atas mengangkat persoalan yang sama, yaitu sampah. Pertama pada foto Seahorse and a Q-Tip, fotojurnalis menggunakan angle sejajar dengan mata manusia, seolah pembaca berada di dalam laut. Komposisi ukuran cotton bud yang lebih besar daripada kuda laut, mengartikan sebuah pesan yang ironis, sampah yang dianggap sepele oleh manusia merupakan ancaman besar bagi biota laut, karena biasanya kuda laut akan melilitkan ekornya hanya pada karang atau rumput laut. Kontras warna subject matter dengan warna biru laut, membuat pembaca fokus kepada kuda laut dan cotton bud serta tidak mementingkan elemen yang lain. Emosi kaget, marah serta takjub pada foto ini, menjelaskan salah satu alasan kenapa fotografi ini bisa viral di internet. Foto kedua, yang akan peneliti bahas adalah foto Trash Wave. Memiliki makna yang sama, foto ini langsung mengundang perasaan jijik bagi siapapun yang melihatnya. Sampah yang bertebaran menguasai komposisi foto tersebut, letak surfer di bagian kiri bawah frame, menjelaskan kepada pembaca bahwa sampah yang berada di lautan sudah sangat banyak. Ke arah manapun surfer itu mengarungi lautan, akan ditemukan sampah dimana-mana. Perbandingan warna biru laut pada gambar sebelah kiri dan sebelah kanan juga cukup signifikan, warna biru laut pada foto sebelah kanan memiliki kandungan warna hijau dan kuning lebih tinggi sehingga menimbulkan efek mual. Kedua foto di atas memperhatikan timing yang sangat tepat, jikalau dipotret berbeda sepersekian detik dari hasil yang didapatkan sekarang, jelas akan berbeda pula makna dan pengaruhnya. Yang menariknya lagi adalah kedua foto tersebut menggunakan visual sebab akibat, relasi manusia dengan sampah atau biota laut dengan sampah. Selalu ada dua obyek utama yang disandingkan pada masing-masing foto. Apakah akan menimbulkan pengaruh yang sama jika yang dipotret hanyalah keadaan laut yang penuh sampah? Peneliti rasa tidak. Dikaitkan dengan teori viralitas yang sudah dibahas pada bab sebelumnya, keduanya membangkitkan emosi yang tidak jauh berbeda. Ada gabungan dari perasaan takjub, kecewa, tidak percaya, jijik hingga terkejut ketika mengamati dua foto tersebut.

\section{SURRENDERING DAN IRAQI GIRL AT CHECKPOINT}

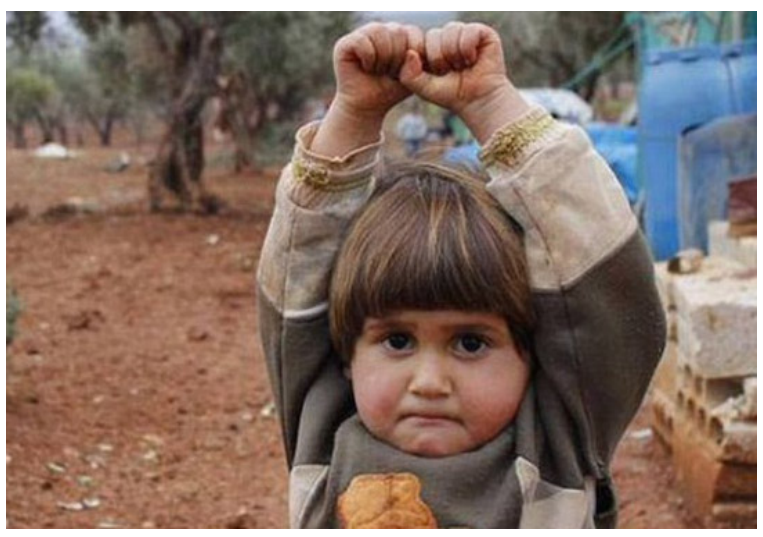

Gambar 9 Surrendering

Sumber: google.com 


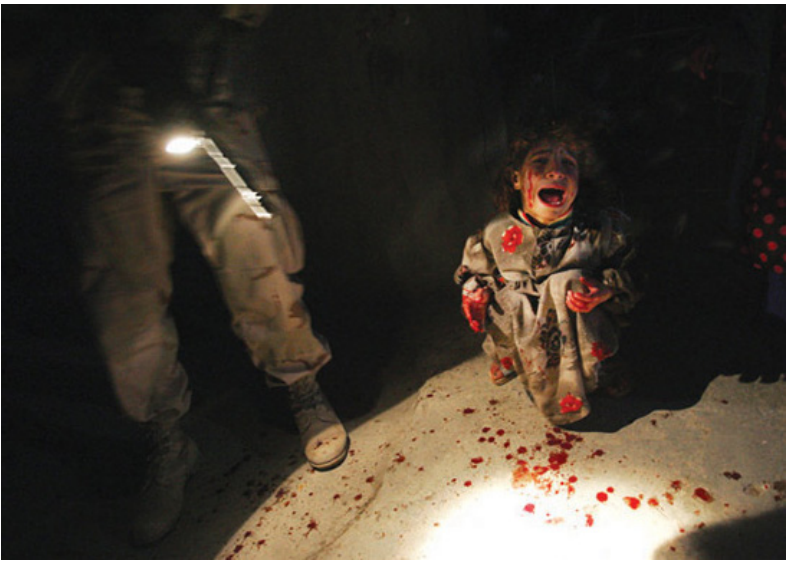

Gambar $10 \quad$ Iraqi Girl at Checkpoint Sumber: google.com

Foto di atas mengangkat isu yang sama, yaitu perang. Foto sebelah kiri terjadi di Syria dan foto sebelah kanan terjadi di Irak. Kedua foto tersebut memaknai arti tragedi, melibatkan anak-anak di bawah umur sebagai subject matter dalam topik yang mencengangkan. Trauma dan kondisi ketakutan mereka tercermin dalam aksi dan reaksi, tangisan ataupun tangisan, keduanya menyedihkan. Foto Surrendering tidak menjelaskan secara eksplisit apa yang terjadi, sampai dimana fotografer menceritakan di surat kabar online bahwa anak Syria tersebut menganggap kamera yang dibawa fotografer adalah sebuah senjata. Cerita foto kedua pun tidak sepenuhnya dimengerti, sampai dimana fotografer menceritakan bahwa itu adalah reaksi seorang anak kecil ketika mendapati ayahnya mati tertembak di bangku setir ketika mereka sedang berkendara. Raut muka dari anak-anak tersebut membangkitkan emosi naik turun untuk para pembacanya. Foto sebelah kanan dengan cipratan darah menekankan situasi tragis yang sedang terjadi di Irak, banyak anak-anak kehilangan orang tuanya di saat yang tidak terduga. Keduanya memperlihatkan sosok subject matter yang lemah dan tidak berdaya. Selain itu, muatan artikel pendek yang menjelaskan kondisi setiap foto tersebut merupakan pendukung kenapa konten fotografi ini bisa menjadi viral di internet.

\section{DAFTAR PUSTAKA}

[1] Argles, M. (2012, November 16). Photojournalism. The Guardian. Retrieved from https://www.theguardian.com/artanddesi gn/2012/nov/16/martin-arglesphotojournalism

[2] Berger, J., \& Milkman, K. L. (2009). Social Transmission and Viral Culture, 1-37. https://doi.org/10.3386/w19846

[3] Bowers, P. J. (2008). Through the Objective Lens: The Ethics of Expression and Repression of High Art in Photojournalism. American Communication Journal, 10(1).

[4] Burhani, R. (2017). UNICEF Soroti Dampak Mengejutkan Perang Suriah Pada Anak-Anak. ANTARA News. Retrieved from https://www.antaranews.com/berita/649 056/unicef-soroti-dampak-mengejutkanperang-suriah-pada-anak-anak

[5] Cruz, R. (2013). EDFAT and The Art of Seeing. Retrieved September 29, 2017, from

https://www.lomography.com/magazine/ 250978-edfat-and-the-art-of-seeing

[6] Goel, S., Anderson, A., Hofman, J., \& Watts, D. J. (2015). The Structural Virality of Online Diffusion. Management Science, 62(1), 180-196. https://doi.org/10.1287/mnsc.2015.2158

[7] Herbert, J. (1998). Working Towards a Practical Theory of Journalism. Asia Pacific Media Educator, 5(12), 137-143.

[8] Jambeck, J. R. (2015). Plastic Waste Inputs from Land to Ocean. Plastic Waste Inputs from Land into the Ocean, 347(January), 
https://doi.org/10.1017/CBO9781107415 386.010

[9] Jones, K., Libert, K., \& Tynski, K. (2016). The Emotional Combinations That Make Stories Go Viral. Retrieved September 28, 2017, from https://hbr.org/2016/05/research-thelink-between-feeling-in-control-andviral-content

[10] Junod, T. (2016). The Falling Man: An Unforgettable Story. Retrieved September 20, 2017, from http://www.esquire.com/newspolitics/a48031/the-falling-man-tomjunod/

[11] Kurniawan, E. (2006). Studi Analisis Isi Pemberitaan Media Massa Tentang Lingkungan Hidup dan Implikasinya Terhadap Kebijakan Pengelolaan Lingkungan di Kabupaten Bangka. Universitas Diponegoro.

[12] Lashmar, P., \& Hill, S. (2014). Online Journalism: The Essential Guide. London: SAGE Publications Ltd.

[13] Oktara, D. (2017, February 6). Pemerintah Berembuk Cari Solusi Sampah Plastik di Laut. TEMPO. Retrieved from https://bisnis.tempo.co/read/843491/pem erintah-berembuk-cari-solusi-sampahplastik-di-laut

[14] Rothman, L. (2012, May 11). The New Photojournalistic Social Advocacy: Nuru Project. TIME. Retrieved from http://time.com/3788456/nuru/

[15] Seuring, S., \& Gold, S. (2012). Conducting Content-Analysis Based Literature Reviews in Supply Chain Management. Supply Chain Management: An International Journal, 17(5), 544-555. https://doi.org/10.1108/13598541211258 609

[16] SNAPSHOT. (2016). Menyelami Foto Jurnalistik: Wawancara Bersama Mithila
Jariwala. Retrieved September 23, 2017, from https://snapshot.canonasia.com/indonesia/article/id/exploringphotojournalism-an-interview-withmithila-jariwala

[17] UNHCR. (2006). The Impact and Effects of War on Children.

[18] Wahyuni, T. (2016, February 23). Indonesia Penyumbang Sampah Plastik Terbesar Kedua Dunia. CNN Indonesia. Retrieved from https://www.cnnindonesia.com/gayahidup/20160222182308-277112685/indonesia-penyumbang-sampahplastik-terbesar-ke-dua-dunia/

[19] White, M. D., \& Marsh, E. E. (2006). Content Analysis: A Flexible Methodology. Library Trends, 55(1), 2245. https://doi.org/10.1353/lib.2006.0053 